\title{
INVOLVEMENT OF THE MITOGEN-ACTIVATED PROTEIN (MAP) KINASE SIGNALLING PATHWAY IN HOST CELL INVASION BY TOXOPLASMA GONDII
}

\author{
ROBERT-GANGNEUX F.*, CREUZET C.*, DUPOUY-CAMET J.* \& ROISIN M.-P.*
}

\begin{abstract}
Summary :
Little is known about signalling in Toxoplasma gondii, but it is likely that protein kinases might play a key role in the parasite proliferation, differentiation and probably invasion. We previously characterized Mitogen-Activated Protein (MAP) kinases in T. gondii lysates. In this study, cultured cells were tested for their susceptibility to Toxoplasma gondii infection after tachyzoite pretreatment with drugs interfering with MAP kinase activation pathways. Protein kinases inhibitors, i.e. genistein, RO3 1-8220 and PD098059, reduced tachyzoite infectivity by $38 \pm 4.5 \%$, $85.5 \pm 9 \%$ and $56 \pm 10 \%$, respectively. Conversely, protein kinases activators, i.e. bombesin and PMA, markedly increased infectivity (by $202 \pm 37 \%$ and $258 \pm 14 \%$, respectively). These results suggest that signalling pathways involving PKC and MAP kinases play a role in host cell invasion by Toxoplasma.
\end{abstract}

KEY WORDS : Toxoplasma gondii, protein kinases, MAP kinases, cell culture, intracellular signalling, cell invasion.

\section{INTRODUCTION}

$\mathrm{P}$ rotein phosphorylation or dephosphorylation is involved in the enzymatic cascades which transduce signals in eukaryotic cells. Signal transduction plays important roles in cell differentiation and proliferation, and in the regulation of metabolic pathways. Phosphatases and kinases have been widely studied in eukaryotic cells, but few data are available on their presence and function in protozoan parasites. An important role of protein kinases and signal transduction has been demonstrated in some protozoan parasites, including Leishmania (Becker \& Jaffe, 1997), Trypanosoma cruzi (Ogueta et al., 1996), Entamoeba bistolytica (Perez et al., 1996), Giardia duodenalis (Chen et al., 1996), and Plasmodium falciparum (Dluzevski \& Garcia, 1996). Indeed, it has been documented that the phosphorylation pattern of Leishmania

\footnotetext{
" Laboratoire Signalisation et Parasites, Université Paris 5, Centre Hospitalier Universitaire Cochin-Port Royal, Pavillon Gustave Roussy, 27, rue du Faubourg Saint-Jacques, 75014 Paris, France.

Correspondence: Florence Robert-Gangneux.

Tel.: 0033.1.58.41.22.51 - Fax: 0033.1.58.41.22.45.

E-mail: florence.gangneux-robert@cch.ap-hop-paris.fr
}

Résumé : RÔLE POSSIBLE D'UNE TRANSDUCTION DU SIGNAL VIA LES "MITOGEN-ACTIVATED PROTEIN" (MAP) KINASES DANS L'INVASION DE LA CELLULE PAR TOXOPLASMA GONDII

II existe peu de données sur les voies de signalisation chez Toxoplasma gondii, mais il est probable que des protéines kinases jovent un rôle dans la croissance, la différenciation, mais aussi l'invasion du toxoplasme. Nous avons précédemment caractérisé des "mitogen-activated protein" (MAPI kinases dans le toxoplasme. Dans cette étude, nous montrons que le pré-traitement des tachyzoïtes par des activateurs (bombésine, PMA) ou des inhibiteurs (génistéine, RO31-8220, PD098059) de protéine kinases intervenant dans la voie d'activation des MAP kinases, entraîne une augmentation ou une diminution de leur pouvoir infectieux pour des cellules 3T3 en culture, respectivement. Ces résultats sont en faveur d'un rôle des voies de signalisation impliquant des protéines kinases $C$ et des MAP kinases dans l'invasion de la cellule par T. gondii.

MOTS CLÉS : Toxoplasma gondii, proteine kinases, MAP kinases, signalisation cellulaire, invasion, culture cellulaire.

and other kinetoplastids varies throughout their life cycle, and may play a key role in parasite survival, differentiation, and cell invasion (Valentine \& Carter, 1993; Hermoso \& Jaffe, 1993 ; Dell \& Engell, 1994; Parsons et al., 1995; Wiese, 1998). Protein kinase inhibitors reduce the infectivity and growth of Leishmania and Trypanosoma cruzi (Vieira et al., 1994; Becker \& Jaffe, 1997). Several protein kinases genes have been identified in Toxoplasma, but their functions remain to be determined (Ng et al., 1995; Ng et al., 1997; Wastling \& Kinnaird, 1998)

We previously demonstrated the presence of mitogenactivated protein (MAP) kinase activity in T. gondii and putatively identified two MAP kinases homologues of the ERK (extracellular signal-regulated kinases) family (Roisin et al., 2000). Gomez-Marin et al. (1998) have also characterized mitogen-activated protein (MAP) kinase activity in $T$. gondii, that was decreased by INF- $\gamma$. As cell invasion and parasite replication within the host cell probably involve protein kinases, we examined the impact of protein kinases inhibitors and activators on Toxoplasma infectivity, focusing on compounds acting at different steps of MAP kinase activation pathways. Activation of MAP kinases (also known as extracellular signal-regulated kinases, or ERK) is one of the most 
rapid cellular responses to various external stimuli, leading to differentiation, growth and other cellular functions (Blenis, 1993). MAP kinase pathway activation occurs through $G$ protein-coupled receptors, calcium channel-coupled receptors, and tyrosine kinase receptors (Treisman, 1996), and is highly dependent on the intracellular calcium concentration and protein kinase $\mathrm{C}$ (PKC) activation (Cobb \& Goldsmith, 1995; Robinson \& Cobb, 1997). In previous experiments, we observed that MAP kinase activity detected in toxoplasma lysates was stimulated by calcium or through PKC activation (Roisin et al., 1999). We therefore tested Toxoplasma infectivity and growth in cultured cells after tachyzoite pretreatment with several compounds: 1) the tyrosine kinase inhibitor genistein, 2) the PKC inhibitor bisindoylmaleimide or RO31-8220 (Chao et al., 1992), 3) the MAP kinase kinase (or MEK) inhibitor PD098059 (Alessi et al., 1995), 4) the PKC activator phorbol-myristyl acetate (PMA) (18), and 5) the PKC and MAP kinase activator bombesin (Pang et al., 1993). Our results point to a role of MAP kinases and PKC in host cell invasion by $T$. gondii.

\section{MATERIALS AND METHODS}

\section{Cell Cultures}

$\perp$ IH-3T3 cells were used for invasion experiments. Briefly, cells were cultured on glass coverslips in 12 -well culture plates $(70,000$ cells per well) overnight at $37^{\circ} \mathrm{C}$ with $5 \% \mathrm{CO}_{2}$, in $1 \mathrm{ml}$ Dulbecco's Eagle modified medium (DMEM) containing $10 \%$ fetal calf serum (FCS), $5 \mathrm{IU} / \mathrm{ml}$ penicillin and $5 \mathrm{Ug} / \mathrm{ml}$ streptomycin. One hour before invasion experiments with Toxoplasma tachyzoites, the medium was removed and replaced with DMEM containing $5 \%$ FCS.

\section{PARASITES}

The RH strain of Toxoplasma gondii was maintained by serial passages in IOPS-OF1 Swiss mice (Iffa Credo, France). Tachyzoites were harvested from peritoneal fluid of mice infected four days earlier. The fluid was centrifuged for $10 \mathrm{~min}$ at $1000 \mathrm{~g}$. The pellet was washed and resuspended in phosphate-buffered saline (PBS) containing $10 \mathrm{IU} / \mathrm{ml}$ penicillin and $10 \mathrm{U} / \mathrm{ml}$ strepto-

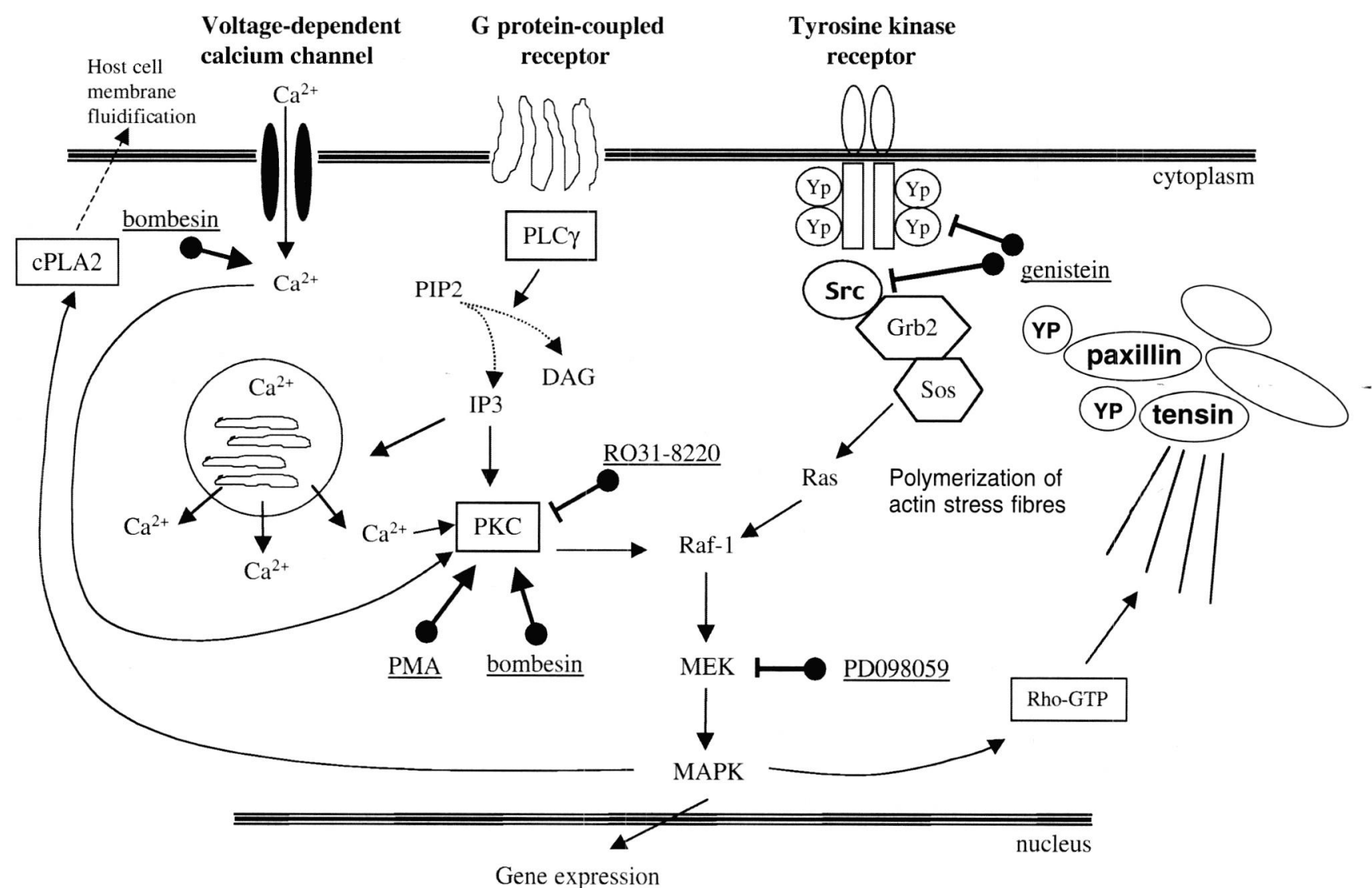

Fig. 1. - Biochemical targets of the different kinase activators $(\bullet)$ or inhibitors $(\bullet)$ used. Three main signalling pathways are concerned: the tyrosine kinase receptors pathway, the G protein-coupled receptors pathway, and the voltage-dependent calcium channels pathway. Abbreviations used: PLC $\gamma$ : phospholipase $C \gamma$; YP: tyrosine phosphorylated residue; PIP2: phosphatidylinositol-4,5-bisphosphate; DAG: diacylglycerol; IP3: inositol trisphosphate; PKC: protein kinase C; MEK: MAP kinase kinase. 
mycin. Tachyzoites were counted and their viability was assessed by trypan blue exclusion method. Parasites were $95 \%$ viable.

\section{TREATMENT OF TACHYZOITES}

\section{AND INVASION EXPERIMENTS}

The site of action in the MAP kinase activation pathway, of the different compounds used, is reported in Figure 1. For drug treatment, tachyzoites $\left(5 \times 10^{6}\right)$ were resuspended in a final volume of $50 \mathrm{ml}$ containing various concentrations of drugs, diluted either in DMEM (genistein (Alexis), RO31-8220 (Alexis, bombesin (Sigma), and PMA [Sigma]), or in $7 \%$ bovine serum albumin (PD098059 (Alexis]), and incubated for $15 \mathrm{~min}$ (all drugs except PD 098059) or $30 \mathrm{~min}$ (PMA and PD098059) at $37^{\circ} \mathrm{C}$ with $5 \% \mathrm{CO}_{2}$. Untreated control tachyzoites were incubated for the same times at $37^{\circ} \mathrm{C}$. For invasion experiments, $10^{6}$ treated or untreated tachyzoites were inoculated per well (parasite:cell ratio 10:1). The volume of inoculum was adjusted so that the final dilution of the drug in the well was at least 1:100 of the initial concentration, thus rending unlikely a direct effect on cell cultures. The absence of any effect on cells of all the drugs applied at such concentrations had been checked previously. After two hours of incubation at $37^{\circ} \mathrm{C}$, Toxoplasma tachyzoites were removed and cells were washed extensively with DMEM then reincubated overnight. The cells were fixed for $30 \mathrm{~min}$ in $4 \%$ paraformaldehyde then washed and kept in PBS until immunofluorescence staining. Each drug experiment was repeated at least three times.

\section{QUANTIFICATION OF HOST CELL INVASION}

- Immunocytofluorescence staining and microscopic quantification

Host cell invasion was quantified by counting after immunocytofluorescence (IF) staining of cell coverslips, using specific anti-Toxoplasma antibodies, as previously described (Creuzet et al., 1998). Coverslips were also incubated for $30 \mathrm{~min}$ with phalloidin (diluted $1: 200$ in PBS containing $2 \%$ FCS and $0.25 \%$ Triton X100 ) in order to visualize precisely cell structure. Coverslips were mounted in Vectashield (Vector, Biosys) and examined under an epifluorescence microscope (Nikon). At least 1000 cells were counted per coverslip. The percentage of infected cells and the mean number of tachyzoites per infected cell were recorded. The data allow a precise quantification of the efficacy of invasion. Results are expressed as the relative reduction or relative increase in cell infection induced by tachyzoite treatment, relative to untreated tachyzoites. Results are presented as mean $( \pm S E)$ infection rates determined in three independent experiments.
- ${ }^{3} \mathrm{H}$-uracil incorporation assay

In some experiments, cell infection was also determined by ${ }^{3} \mathrm{H}$-uracil incorporation assay, as previously described (Pfefferkorn \& Pfefferkorn, 1977). In this latter case, identical numbers of cultured cells $\left(10^{4}\right.$ cells $\left./ \mathrm{cm}^{2}\right)$ were seeded on coverslips. Cells were infected with $2 \times 10^{5}$ treated or untreated parasites per well for $2 \mathrm{~h}$, then washed and incubated for the next $24 \mathrm{~h}$ in labeling medium containing dialyzed FCS (3\%) and (5-6)$\left[{ }^{3} \mathrm{H}\right]$-uracil $(2 \mu \mathrm{Ci} / \mathrm{ml}$, Amersham). The medium was then discarded, cells were lysed in PBS containing $1 \%$ sodium dodecyl sulfate and $1 \mathrm{mM}$ uracil, and protein was precipitated with trichloracetic acid (10\% final concentration). Precipitates were washed on GF/C filters (Whatmann), and the radioactivity on filters was counted in a scintillation counter. This technique allows to quantify the parasite mutiplication, and thus reflects roughly the efficacy of invasion. Results are expressed as the ratio incorporation rate of control tachyzoites : incorporation rate of treated tachyzoites. The results are presented as the means ( \pm SE) of at least three independent experiments.

\section{RESULTS}

EFFECT OF PROTEIN KINASE INHIBITORS ON CELL INVASION AND PARASITE GROWTH

$T$ Toxoplasma tachyzoites incubated with the PKCinhibitor RO31-8220 showed reduced infectivity for $3 \mathrm{~T} 3$ cells, in a dose-dependent manner (Fig. 2A). The percentage of infected cells counted after IF staining decreased by $55 \pm 8 \%$ ( $t$ Student test, $p<0.01)$ when parasites were submitted to $100 \mu \mathrm{M}$ RO31-8220 for $15 \mathrm{~min}$ before cell contact. In addition, the number of parasites per infected cell, counted after overnight incubation of infected cells, showed a marked decrease, from $6( \pm 0.8)$ tachyzoites/cell (control) to $3.5( \pm 0.6)(100 \mu \mathrm{M}$ RO31-8220), suggesting reduced parasite replication (not shown). The assessment of parasite growth by $\left[{ }^{3} \mathrm{H}\right]$-uracil incorporation supported these data by demonstrating a marked dose-dependent fall in radioactivity incorporation, to $6.4 \pm 2.1 \%$ of control at $100 \mu \mathrm{M}$ ( $t$ Student test, $p<0.01$ ), and reflecting both reduced infectivity and reduced parasite replication (Table I).

Parasite incubation with genistein, a tyrosine kinase inhibitor, reduced infectivity by $38 \pm 4.5 \%$ compared to the control ( $t$ Student test, $p<0.01$ ), but only at a high concentration (Fig. 2B). Similarly, $\left[{ }^{3} \mathrm{H}\right]$-uracil incorporation showed a slight decrease (Table I). Parasite replication was not significantly altered, as the mean number of parasites per infected cell was not different from the control value (not shown). 


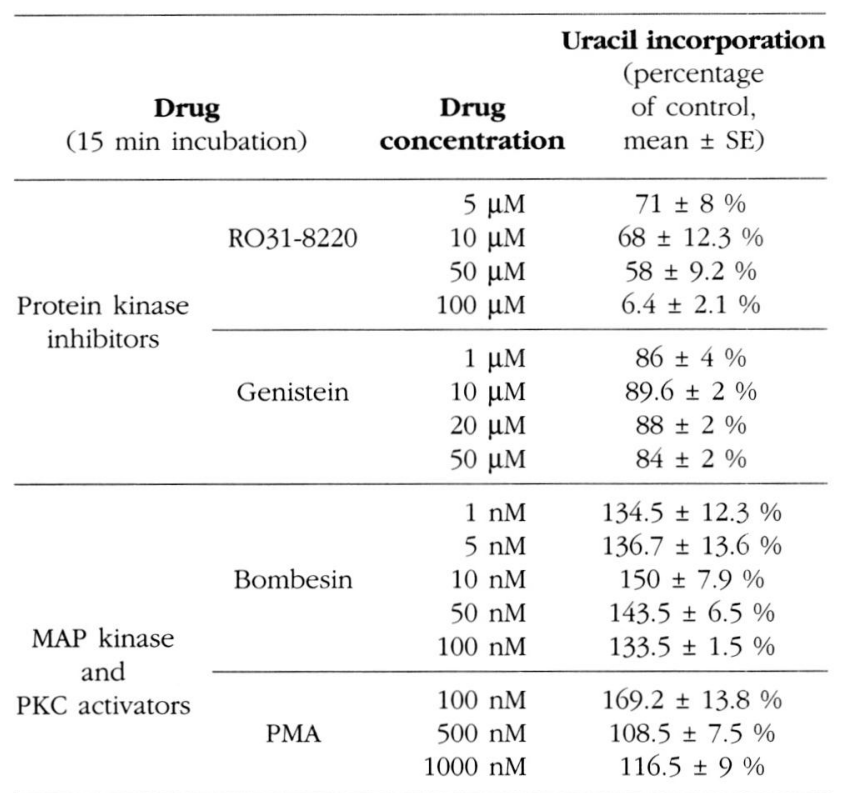

Data are means \pm SE of three independent experiments

Table I. - Effects of protein kinase inhibitors and activators on the intracellular development of $T$. gondii in vitro. Quantification by $\left[{ }^{3} \mathrm{H}\right]-$ uracil incorporation after $24 \mathrm{~h}$ culture.

By contrast, parasite preincubation for $30 \mathrm{~min}$ with PD098059, a MEK inhibitor, led to a marked decrease in Toxoplasma infectivity (- $50 \%$ at $10 \mu \mathrm{M}$ ) (Fig. 2C) ( $t$ Student test, $p<0.001$ ).

\section{EFFECT OF KINASES ACTIVATORS ON PARASITE INFECTIVITY AND GROWTH}

Tachyzoite preincubation for 15 min with bombesin resulted in a marked increase in Toxoplasma infectivity, which reached $202.6 \pm 37 \%$ of the control value at $50 \mathrm{nM}$ ( $t$ Student test, $p<0.001$ ) (Fig. 3A). Quantification of parasite replication by $\left[{ }^{3} \mathrm{H}\right]$-uracil incorporation yielded similar but lower results (Table I).

Similarly, the PKC activator PMA led to an increase in infectivity, which reached $258 \pm 14 \%$ of control at $500 \mathrm{nM}$ after $30 \mathrm{~min}$ of stimulation (t Student test, $\mathrm{p}<$ 0.001) (Fig. 3B). PMA also increased infectivity after 15 min of stimulation, but to a lesser degree (+ $150 \%)$. Whatever the incubation time, higher PMA concentrations had no effect on infectivity. This type of dose response is commonly observed with PMA, the effect of which is both dose- and time-dependent. $\left[{ }^{3} \mathrm{H}\right]$-uracil gave similar results (Table I).

\section{DISCUSSION}

I $\mathrm{t}$ is likely that protein kinases play a key role in many cellular process in Toxoplasma, as well as in other eukaryotic cells. In this study we examined several signalling pathways leading to MAP kinase activation, by pre-treating parasites with several protein kinases inhibitors and protein kinases activators. The quantification of host cell invasion was assessed

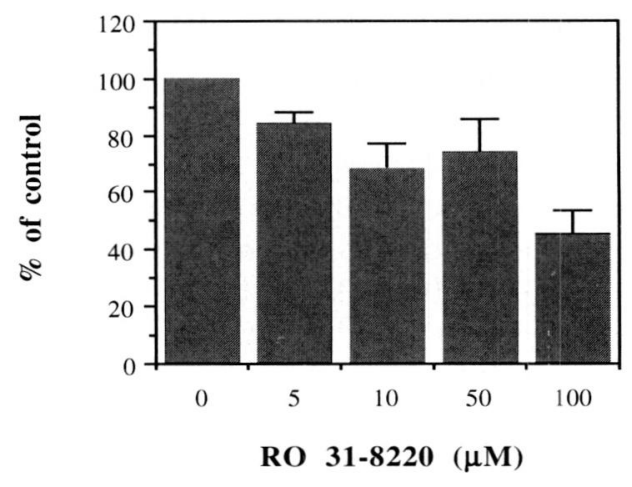

A

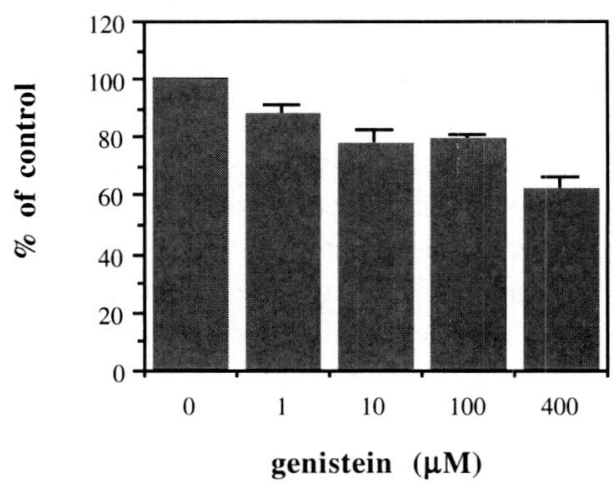

B

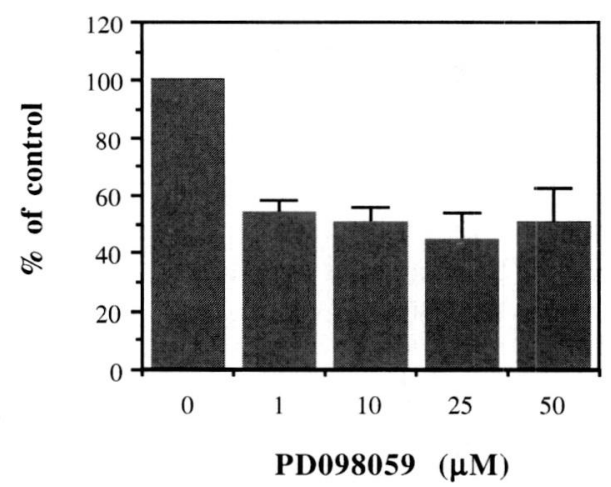

Fig. 2. - Effects of protein kinase inhibitors on Toxoplasma infectivity.

Toxoplasma tachyzoites were preincubated with increasing concentrations of RO31-8220 for $15 \mathrm{~min}$ (A), genistein for $15 \mathrm{~min}(\mathrm{~B})$, or PD098059 for $30 \mathrm{~min}$ (C).

The efficacy of invasion was evaluated by microscopic counting of the percentage of infected cells. Results are expressed as relative percentages, corresponding to the relative decrease of cell infection, compared to control values (cell infection by untreated tachyzoites, i.e., $25.5 \pm 6.9 \%$ in (A), $20 \pm 2.5 \%$ in (B) and $34.5 \pm 4.5 \%$ in (C)), arbitrarily brought to $100 \%$. Data are the means \pm SE of three independent experiments. 


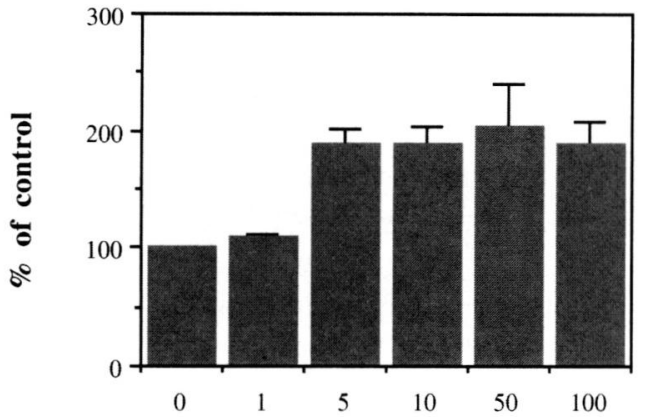

Bombesin (nM)

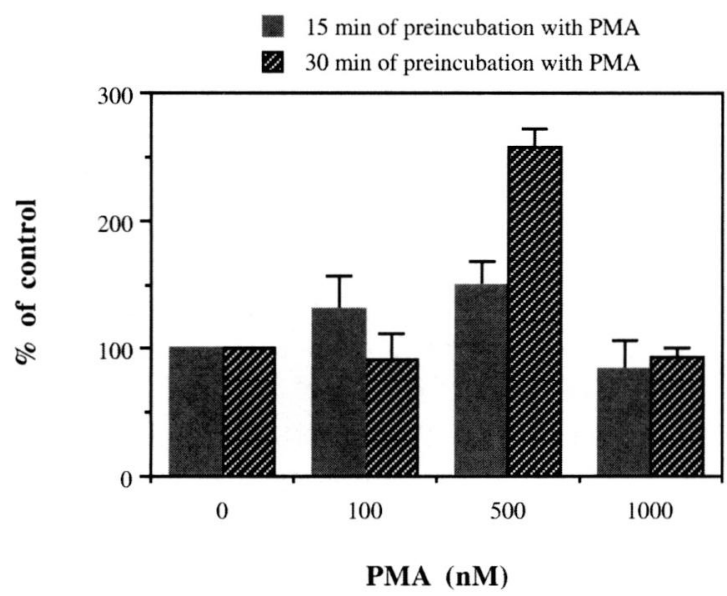

Fig. 3. - Effects of MAP kinase and PKC activators on Toxoplasma infectivity.

Toxoplasma tachyzoites were preincubated with increasing concentrations of bombesin for $15 \mathrm{~min}$ (A), or PMA for $15 \mathrm{~min}$, or $30 \mathrm{~min}$ (B).

The efficacy of invasion was evaluated by microscopic counting of the percentage of infected cells after immunofluorescence staining. Results are expressed as relative percentages, corresponding to the relative increase of cell infection, compared to control values (cell infection by untreated tachyzoites, i.e., $20.2 \pm 5.5 \%$ in (A), $18.5 \pm$ $2.1 \%$ in (B)), arbitrarily brought to $100 \%$. Data are means \pm SE of three independent experiments.

by two different methodologies: $i$ ) by counting infected host cells after overnight culture, which directly reflects the efficacy of invasion, and $i$ ) by $\left[{ }^{3} \mathrm{H}\right]$-uracil incorporation after 24 hours, which mostly reflects intracellular growth and more undirectly invasion. Although these two techniques do not measure exactly the same event, we present here the results obtained with both methods of quantification, which were comparable for all the drugs tested.

Genistein, a tyrosine kinase inhibitor, had only a moderate inhibitory effect on parasite infectivity, suggesting that tyrosine kinases are not a major signalling pathway involved in cell invasion. Other authors have reported different results with another protozoan parasite, T. cruzi (Vieira et al., 1994; Favoreto et al., 1998). They showed that genistein inhibited macrophages infection by T. cruzi by up to $90 \%$. In other studies, genistein prevented proliferation of $T$. brucei (Wheeler-Alm \& Shapiro, 1992) and Listeria (Velge et al., 1994).

By contrast, tachyzoite stimulation with bombesin, which activates MAP kinases in Swiss-3T3 cells (Pang et al., 1993), had a marked effect on both parasite infectivity and growth, as measured by both techniques of quantification, suggesting that MAP kinases are a major crossing pathway in parasite signalling. In our experiments, tachyzoite activation with bombesin stimulated host cell invasion 2 -fold. In addition, preincubation of cell cultures with $50 \mathrm{nM}$ bombesin led to a significant increase in Toxoplasma infectivity (not shown), suggesting that signalling pathways involving MAP kinases in both the host cell and the parasite could be involved in the invasion process. Similarly, prestimulation of tachyzoites with PMA, a PKC activator (Kraft \& Anderson, 1983), also induced a large increase in infectivity. As PKC is involved in MAP kinase activation (Garrington \& Johnson, 1999), these results support a role of MAP kinases in Toxoplasma invasion. MAP kinase activation through PMA is a transient and reversible event, which is both time- and dose-dependent. For this reason, the effect of this drug on tachyzoite invasion was observable only when a given concentration was applied for a given time period, i.e: $500 \mathrm{nM}$ for $30 \mathrm{~min}$, as assessed by microscopic counting. Conversely, tachyzoite treatment with RO31-8220, a PKC inhibitor, significantly reduced both parasite infectivity and growth, as shown by the near-abolition of uracil incorporation. Taken together, these results could confirm a role of MAP kinases via PKC activation. It was reported that PMA can increase host cell infection by T. cruzi (Vieira et al., 1994), while staurosporine, a PKC inhibitor, has a profound effect on the division and morphology of Leishmania promastigotes (Becker \& Jaffé, 1997) and inhibits erythrocyte invasion by $P$. knowlesi (Ward et al., 1994), both effects suggesting a role of PKC in kinetoplastid survival and infectivity.

To confirm the increase in infectivity occurring via MAP kinase activation, we preincubated Toxoplasma tachyzoites with PD098059, a specific inhibitor of MEK. MEK is an upstream dual-specific MAP kinase kinase that activates the MAP kinases ERK1 and ERK2 by phosphorylation of Thr-183 and Tyr-185 residues (Her et al., 1993). Host cell infection by tachyzoites pretreated with PD098059 was markedly inhibited, pointing to activation of ERK1- or ERK2-like proteins in T. gondii invasion process. Similar results have been obtained using another in vitro model (Gomez-Marin et al., 1998).

Taken together, our results suggest that ERK-like kinases may be involved in Toxoplasma infectivity 
and growth, at least in vitro, through PKC activation. In other pathogens, such as Listeria and Salmonella typhimurium, the ERK pathway is required for host cell invasion (Pace et al., 1993; Hobbie et al., 1997; Tang \& Sutherland, 1998). The involvement of MAP kinase pathways in the invasion process could be related to various roles of MAP kinases in eukaryotic cells, such as: $i$ ) cytoskeleton regulation and formation of actin stress fibers through the small GTP-binding protein Rho (Ridley \& Hall, 1994), ii) activation of PLA2 (Hirasawa et al., 1995; Xing et al., 1996), and iii) exocytosis of secretory vesicles (Cox \& Parsons, 1997). In particular, the role of MAP kinases in Toxoplasma infectivity could be explained in several ways. First, a PLA2 from the parasite is known to be required for host cell penetration (Saffer \& Schwartzman, 1991), an enzyme which could be activated by parasite MAP kinases. The invasion process takes place in several stages, including cell-surface recognition, parasite attachment, and exocytosis of specific secretory organelles (rhoptries and micronemes), that could depend on MAP kinase activation. Finally, the parasite actin cytoskeleton is essential for its motility and entry into the host cell, as demonstrated by the inhibition of invasion by cytochalasin D (Dobrowolski \& Sibley, 1996). As MAP kinases (also known as microtubule-associated protein kinases) are involved in the polymerization of actin stress fibers through small GTP-binding protein, they may also contribute to parasite motility and invasiveness.

In conclusion, our results point to the involvement of MAP kinase signalling pathways in the host cell invasion by Toxoplasma gondii, possibly via PKC activation.

\section{ACKNOWLEDGEMENTS}

his work was supported by Université Paris 5 , Faculté de Médecine Cochin-Port Royal and ADERMEPT. We thank Odile Puijalon (Pasteur Institute, Paris) for helpful discussions, and David Young for the English revision of the manuscript.

\section{REFERENCES}

Alessi D.R., Cuenda A., Cohen P., Dudley D. \& Saltiel A.R. PD 98059 is a specific inhibitor of the activation of mitogenactivated protein kinase kinase in vitro and in vivo. Journal of Biological Chemistry, 1995, 270, 27489-27494.

BECKER S. \& JAFFE C.L. Effect of protein kinase inhibitors on the growth, morphology, and infectivity of Leishmania promastigotes. Parasitology Research, 1997, 83, 273-280.

BLENIS J. Signal transduction via the MAP kinases: proceed at your own RSK. Proceedings of the National Academy of Sciences USA, 1993, 90, 5889-5892.
Chao T.S.O., Byron K.L., Lee K.M., Villereal M. \& Rosner M.R. Activation of MAP kinases by calcium-dependent and calcium-independent pathways. Journal of Biological Chemistry, 1992, 267, 19876-19883.

Chen N., Upcroft J.A. \& Upcroft P. A novel protein kinase gene family in Giardia duodenalis. Gene, 1996, 177, 191194.

CoBb M.H. \& Goldsmith E.J. How MAP kinases are regulated. Journal of Biological Chemistry, 1995, 270, 14843-14846.

Cox M.E. \& PARSONS S.J. Roles for protein kinase $C$ and mitogen-activated protein kinase in nicotine-induced secretion from bovine adrenal chromaffin cells. Journal of Neurochemistry, 1997, 69, 1119-1130.

Creuzet C., Robert F., Roisin M.P., Van Than H., Benes C., DupouY-CAMET J. \& FAGARD R. Neurons in primary culture are less efficiently infected by Toxoplasma gondii than glial cells. Parasitology Research, 1998, 84, 25-30.

Dell K.R. \& ENGel J.N. Stage-specific regulation of protein phosphorylation in Leishmania major. Molecular and Biochemical Parasitology, 1994, 64, 283-292.

Dluzewski A.R. \& GaRCIA C.R. Inhibition of invasion and intraerythrocytic development of Plasmodium falciparum by kinase inhibitors. Experientia, 1996, 52, 621-623.

DOBROWOLSKI J.M. \& SiBLEY L.D. Toxoplasma invasion of mammalian cells is powered by the actin cytoskeleton of the parasite. Cell, 1996, 84, 933-939.

FAvoreto S., DORTA M.L. \& Yoshida N. Trypanosoma cruzi $175-\mathrm{kDa}$ protein tyrosine phosphorylation is associated with host cell invasion. Experimental Parasitology, 1998, 89, 188-194.

GaRRINGTON T.P. \& JohnSON G.L. Organization and regulation of mitogen-activated protein kinase signaling pathways. Current Opinion in Cell Biology, 1999, 11, 211-218.

Gomez-Marin J.E., Valere A., Bonhomme A., El'btaouri H., Antonicelli F., Burlet H., Aubert D., Villena I., GuenouNOU M., HAYE B. \& PINON J.M. Interferon-g signal transduction during parasite infection: modulation of MAP kinases in the infection of human monocyte cells (THP1) by Toxoplasma gondii. Parasite Immunology, 1998, 20, 631-635.

Her J.H., Lakhani S., Zu K., Vila J., Dent P., Sturgill T.W. \& WeBER M.J. Dual phosphorylation and autophosphorylation in mitogen-activated protein (MAP) kinase activation. Biochemical Journal, 1993, 296, 25-31.

Hermoso T. \& Jaffe C.L. Phosphorylation of proteins in virulent promastigotes from Leishmania major. Biological Research, 1993, 26, 267-271.

Hirasawa N., Santini F. \& Beaven M.A. Activation of the MAP kinase/cytosolic PLA2 pathway in a rat mast cell line. Indications of different pathways for release of arachidonic acid and secretory granules. Journal of Immunology, 1995 , 154, 5391-5402.

Hobbie S., Mei-Chen L., Davis R.J. \& Galan J. Involvement of mitogen-activated protein kinase pathways in the nuclear responses and cytokine production induced by Salmonella typhi-murium in cultured intestinal epithelial cells. Journal of Immunology, 1997, 159, 5550-5559. 
KRAFT A.S. \& ANDERSON W.B. Phorbol esters increase the amount of calcium, phospholipid-dependent protein kinase associated with plasma membranes. Nature, 1983, 301, 621-623.

Ng H.C., Singh M. \& Jeyaseelan K. Identification of two protein serine/threonine kinase genes and molecular cloning of a SNF1 type protein kinase gene from Toxoplasma gondii. Biochemical and Molecular Biology International, 1995, 35, 155-165.

Ogueta S., Intosh G.M. \& Tellez I.M. Regulation of $\mathrm{Ca}^{2+} / \mathrm{cal}-$ modulin-dependent protein kinase from Trypanosoma cruzi. Molecular and Biochemical Parasitology, 1996, 78, 171-183.

Pace J., Hayman M. J. \& Galan J.E. Signal transduction and invasion of epithelial cells by $S$. typhi-murium. Cell, 1993, 72, 505-514.

Pang L., Decker S.J. \& Saltiel A.R. Bombesin and epidermal growth factor stimulate the mitogen-activated protein kinase through different pathways in Swiss 3T3 cells. Biochemical Journal, 1993, 289, 283-287.

Parsons M., Carter V., Muthiani A. \& Murphy N. Trypanosoma congolense: developmental regulation of protein kinases and tyrosine phosphorylation during the life cycle. Experimental Parasitology, 1995, 80, 507-514.

PARSONS M., VAlENTINE M. \& CARTER V. Protein kinases in divergent eukaryotes: identification of protein kinase activities regulated during Trypanosoma development. Proceedings of the National Academy of Sciences USA, 1993, 90, 26562660.

Perez E., Munoz M.L. \& Ortega A. Entamoeba bistolytica: involvement of pp125FAK in collagen-induced signal transduction. Experimental Parasitology, 1996, 82, 164-170.

PfEFFERKorn E.R. \& PFefFERKorn L.C. Specific labeling of intracellular Toxoplasma gondii with uracil. Journal of Protozoology, 1977, 24, 449-453.

QIN C.L., TANG J. \& KIM K. Cloning and in vitro expression of TPK3, a Toxoplasma gondii homologue of shaggy/glycogen synthase kinase-3 kinases. Molecular and Biochemical Parasitology, 1998, 93, 273-283.

RIDLEY A. \& HALl A. Signal transduction pathways regulating Rho-mediated stress fibre formation: requirement for a tyrosine kinase. EMBO Journal, 1994, 13, 2600-2610.

RoBinson M.J. \& CoBB M.H. Mitogen-activated protein kinase pathways. Current Opinion in Cell Biology, 1997, 9, 180186.

Roisin M.P., Robert-Gangneux F., Creuzet C., Dupouy-Camet J. Biochemical characterization of mitogen-activated protein (MAP) kinase activity in Toxoplasma gondii. Parasitology Research, 2000, in press.

SAFFER L.D. \& SCHWARTZMAN J.D. A soluble phospholipase of Toxoplasma gondii is associated with host cell penetration. Journal of Protozoology, 1991, 38, 454-460.

TANG P., Sutherland C.L., Gold M.R. \& Finlay B.B. Listeria monocytogenes invasion of epithelial cells requires the MEK-1/ERK-2 mitogen-activated protein kinase pathway. Infection and Immunity, 1998, 66, 1106-1112.

TREISMAN R. Regulation of transcription by MAP kinase cascades. Current Opinion in Cell Biology, 1996, 8, 205-215.
Velge P., Bottreau E., Kaeffer B., Yurdusev N., Pardon P. \& VAN LANGENDONCK N. Protein tyrosine kinase inhibitors block the entries of Listeria monocytogenes and Listeria ivanovii into epithelial cells. Microbial Pathology, 1994, 17, 37-50.

Vieira M.C., De Carvalho T.U. \& De Souza W. Effect of protein kinase inhibitors on the invasion process of macrophages by Trypanosoma cruzi. Biochemical and Biophysical Research Communications, 1994, 203, 967-971.

Villalta F., Zhang Y., BibB K.E., Burns J.M. \& Lima M.F. Signal transduction in human macrophages by gp83 ligand of Tryanosoma cruzi: trypomastigote gp83 ligand up-regulates trypanosome entry through the MAP kinase pathway. Biochemical and Biophysical Research Communications, 1998, 249, 247-252.

Ward G.E., Fugioka H., Aikawa M. \& Miller L.H. Staurosporine inhibits invasion of erythrocytes by malarial merozoites. Experimental Parasitology, 1994, 79, 480-487.

WASTLING J.M. \& KinNAIRD J.H. Isolation and characterization of a genomic clone encoding a cdc- 2 related kinase of Toxoplasma gondii. Molecular and Biochemical Parasitology, 1998, 94, 143-148.

WheElER-Alm E. \& SHAPIRO S.Z. Evidence of tyrosine kinase activity in the protozoan parasite Trypanosoma brucei. Journal of Protozoology, 1992, 39, 413-416.

WIESE M. A mitogen-activated protein (MAP) kinase homologue of Leishmania mexicana is essential for parasite survival in the infected host. EMBO Journal, 1998, 17, 26192628.

Xing M., Firestein B.L., Shen G.H. \& Insel P.A. Dual role of protein kinase $\mathrm{C}$ in the regulation of CPLA2 sub 2-mediated arachidonic acid release by $\mathrm{P}$ sub $2 \mathrm{U}$ receptors in MDCK-D sub 1 cells: involvement of MAP kinases dependent and independent pathways. Journal of Clinical Investigations, 1997, 99, 805-814.

Reçu le 17 janvier 2000 Accepté le 3 avril 2000 